\title{
REGISTER DALAM PROFESI ADVOKAT: KAJIAN BENTUK, FUNGSI, DAN MAKNA
}

\author{
Hasiana Naulita Siahaan, Agung Pramujiono \\ (Pendidikan Bahasa dan Sastra Indonesia, Fakultas Keguruan dan Ilmu Pendidikan, \\ Universitas PGRI Adi Buana Surabaya) \\ hasiananaulita@yahoo.co.id, agungpramujiono.unipasby@gmail.com
}

\begin{abstract}
ABSTRAK
Bahasa memiliki peran penting. Bahasa adalah sesuatu yang unik dan universal. Unik berarti memiliki ciri khas yang tidak dimiliki oleh bahasa orang lain dan berarti universal memiliki sifat yang sama dengan bahasa orang lain. Manusia tidak dapat hidup tanpa bahasa, karena mereka adalah sekelompok manusia yang saling berkomunikasi. Jadi, fungsi bahasa secara umum adalah alat komunikasi antara orang dengan orang lain yang dihasilkan oleh orang itu sendiri untuk menyampaikan perasaan atau menyampaikan gagasan kepada orang lain. Banyak sekali permasalahan yang ada di masyarakat, di lingkungan seperti masalah hukum. Sehingga saya sebagai peneliti tertarik dengan hukum dan saya pikir profesi advokat akan selalu menemukan keadilan bagi kliennya. Tujuan dari penelitian ini adalah untuk mengetahui dan mendeskripsikan tentang register profesi advokat di Indonesia dan menjelaskan karakteristik penggunaan bahasa yang digunakan oleh advokat dalam mengambil peran dewan dan berkomunikasi dalam sehari-hari, karena masyarakat sebagian besar dari mereka tidak tahu tentang penggunaan bahasa dalam undang-undang. Kemudian, peneliti akan menjelaskan ciri-ciri bahasa yang digunakan dalam diksi yang digunakan oleh advokat dalam mengadukan masalah yang dihadapi dewan dan berkomunikasi di luar ruang dewan. Teori utama yang digunakan berkaitan dengan beberapa teori dalam linguistik tentang bahasa dan masyarakat. Pendekatan yang digunakan dalam penelitian ini adalah kualitatif dalam bentuk deskripsi. Metode yang digunakan menggunakan wawancara. Teknik pengumpulan data yang digunakan dilakukan dengan teknik dialog, rekam, dan catat. Wawancara khusus dilakukan dengan wawancara informal dengan wawancara pribadi dan wawancara kelompok dengan advokat. Hasil penelitian ini menunjukkan bentuk, fungsi dan makna register advokat di Indonesia. Bentuknya dapat dilihat dari diksi, sedangkan fungsi berpusat pada fungsi regulatorik karena mengatur dan mengontrol masyarakat melalui hukum, dan pemaknaan menggunakan makna referensial.
\end{abstract}

Kata kunci: Register, Bahasa, Advokat

\section{PENDAHULUAN}

Manusia merupakan makhluk sosial, sehingga selalu berkomunikasi dengan sesamanya menggunakan bahasa. Bahasa bersifat unik dan universal. Unik artinya memiliki ciri atau sifat khas yang tidak dimiliki bahasa lain, dan universal artinya memiliki ciri yang sama pada semua bahasa. Bahasa dan lingkungan masyarakat merupakan kesatuan yang tidak dapat dipisahkan. Maksudnya, manusia merupakan makhluk sosial yang tidak dapat hidup sendiri melainkan selalu berinteraksi dengan sesamanya. 
Jadi, fungsi bahasa secara umum merupakan alat komunikasi antara masyarakat satudengan masyarakat lain yang dihasilkan oleh alat ucap manusia.Bahasa sebagai kebutuhan manusia dapat berwujud bahasa tulisan dan bahasa lisan. Bahasa lisan memiliki berbagai macam bentuk, seperti bahasa yang digunakan dokter dengan pasien, polisi dengan masyarakat, advokat dengan klien, dan sebagainya. Penulis akan membahas tentang variasi atau ragam kebahasaan yang dimiliki oleh advokat Indonesia, khususnya di Surabaya.

Karena tidak banyak masyarakat umum yang mengenal dan mengetahui tentang kebahasaan yang mereka pakai atau miliki. Menurut Halliday (1994:56) register merupakan bahasa yang digunakan saat ini, tergantung pada apa yang sedang dikerjakan dan sifat kegiatannya. Contoh ekstrim dalam perbedaan register adalah bahasa terbatas dan bahasa untuk tujuan khusus, yakni register yang telah berkembang untuk maksud tertentu, yang dengan sendirinya terbatas. Contoh register yang tidak ekstrim adalah variasi dalam lingkungan kerja yang bersifat teknis (seperti ilmiah, teknologi), kelembagaan (seperti dokter-pasien, advokat-klien), konteks lain yang memiliki struktur dan strategi khusus (seperti diskusi, dan sebagainya).

Di dalam kehidupan sosial terdapat beberapa kelompok profesi, misalnya guru, dokter, polisi, advokat, dan lain-lain. Salah satu kelompok profesi yang menarik untuk diteliti yakni di bidang hukum, khususnya yang berprofesi sebagai advokat. Karena terdapat banyak variasi-variasi bahasa (seperti penggunaan register, bahasa Inggris dan bahasa Belanda) yang digunakannya dalam berkomunikasi di luar maupun di dalam sidang perkara.

Dalam menegakkan keadilan untuk masyarakat, suatu sidang di pengadilan hukum, terutama advokat memiliki bahasa yang masyarakat umum terkadang tidak banyak yang mengetahui dan memahaminya. Oleh karena itu, penelitian ini dianggap penting untuk dilakukan agar masyarakat atau peneliti berikutnya dapat mengetahui dan memahami bahasa advokat secara umum.

Melihat paparan di atas, penelitian ini ingin menjawab beberapa pe

rmasalahan, bagaimana bentuk register advokat, bagaimana fungsi register advokat, dan apakah makna register advokat di Surabaya? Yang hasilnya dapat bermanfaat khusus bagi peneliti berikutnya sebagai bahan referensi untuk mengembangkan kebahasaan dalam register advokat. Dengan demikian, penelitian ini bertujuan untuk mengetahui bentuk dalam wujud register advokat, fungsi bahasa register advokat, dan makna bahasa register advokat.

\section{METODE PENELITIAN}

Pendekatan penelitian ini menggunakan pendekatan kualitatif dan jenis penelitian ini menggunakan jenis deskriptif.Metode penelitian ini menggunakan metode wawancara. Peneliti mendapatkan datanya berdasarkan kenyataan yang ada di lapangan, meliputi kata, ungkapan, istilah maupun bahasa yang digunakan oleh kalangan advokat di Surabaya. Setelah itu peneliti mendeskripsikan data yang telah diperolehnya mengenai kelompok di bidang hukum, khususnya yang berprofesi sebagai advokat.

Teknik penelitian ini menggunakan teknik cakap, rekam, dan catat.Menurut Mahsun (2012:121), teknik cakap semuka merupakan teknik peneliti langsung mendatangi setiap daerah pengamatan dan melakukan percakapan dengan sumber informan. Teknik rekam ini dikolaborasikan dengan 
teknik catat, karena data yang diperoleh dengan mencatat dapat diperiksa kembali dengan hasil rekaman. Teknik catat hanya digunakan untuk mengetahui realisasi dari artikulasi yang diujarkan oleh informan.

Pengumpulan data penelitian inidiambil dari data lisan berupa kosakata atau istilah bahasa yang diujarkan di bidang hukum, sedangkan sumber datanya dari beberapa advokat di Surabaya yaitu Toba Siahaan S.H sebagai sumber informan pertama dan Alexander Arif S.H, C.H sebagai sumber informan kedua.Wawancara ini dilakukan di kantor Advokat "Alexander Arif S.H., C.N" di jalan Sidodadi nomor 14 Surabaya sejak tanggal 08 Oktober 2015 - 08 Januari 2016.

\section{HASIL PENELITIAN}

1. Bentuk register: praduga tak bersalah

Fungsi bahasanya menggunakan fungsi referensial, yaitu fungsi yang memiliki referen atau sebagai alat untuk membicarakan atau menyatakan peristiwa yang ada di sekelilingnya. Makna bahasanya menggunakan makna referensial, karena maknanya mengandung sumber acuan. Praduga tak bersalah memiliki arti sebagai istilah dalam menyebutkan seseorang yang belum terbukti bersalah.

Konteks: Untuk saat ini kasus pembunuhan mirna yang dituduhkan kepada jessica dinyatakan sebagai praduga tak bersalah, karena bukti-bukti yang ada belum cukup membuktikan jessica sebagai pelaku.

2. Bentuk register: prematur

Fungsi bahasanya menggunakan fungsi informasional, yaitu fungsi bahasa yang digunakan untuk menginformasikan sesuatu. Makna bahasanya menggunakan makna leksikal, karena maknanya sungguh-sungguh nyata dalam kehidupan. Prematur memiliki arti sebagai istilah ketidakjelasan dalam tuduhan suatu kasus atau tuduhannya kabur/tidak jelas/masih dini.

Konteks: Dalam kasus curanmor itu dianggap prematur karena tuduhannya masih dini.

3. Bentuk register: vonis

Fungsi bahasanya menggunakan fungsi bahasa konatif, yaitu bahasa yang terarah pada lawan bicara.Makna bahasanya menggunakan makna konseptual, karena maknanya sesuai konsep. Vonis memiliki arti sebagai istilah suatu putusan hakim dalam memberikan hukuman terhadap terpidana.

Konteks: Hakim telah memutuskan vonis lima tahun penjara kepada terpidana kasus narkoba.

4. Bentuk register: konsinyasi

Fungsi bahasanya menggunakan fungsi informasional, yaitu untuk menginformasikan sesuatu.Makna bahasanya menggunakan makna leksikal, karena maknanya sungguh-sungguh nyata dalam kehidupan. Konsinyasi memiliki arti sebagai istilah hukum untuk penitipan uang kepada pengadilan (misalnya apabila penagih hutang menolak menerima pembayaran).

Konteks: Dalam kasus pembayaran cicilan mobil dalam suatu perusahaan ACC, seseorang membayar cicilan mobil yang memilikitunggakan selama 2 bulan, kemudian pihak ACC tidak mau menerima uang tersebut. Seseorang tersebut dapat mengajukan gugatan ke pengadilan lalu menitipkan uang sebagai konsinyasi atas hutang penggugat. 
5. Bentuk register: $\mathrm{P} 21$

Fungsi bahasanya menggunakan fungsi informasional, yaitu untuk menginformasikan sesuatu. Sesuatu yang dimaksud di sini adalah berkas yang sudah ternilai sempurna dan selanjutnya dapat diproses secara hukum yang berlaku.Makna bahasanya menggunakan makna leksikal, karena maknanya sesuai dengan hasil observasi alat indra atau makna yang sungguh-sungguh nyata. P21 memiliki arti sebagai kesempurnaan berkas penyelidikan polisi yang akan segera dilimpahkan ke kejaksaan atau hasil penyelidikan yang sudah lengkap/sempurna.

Konteks: Berkas dari kasus pencurian tersebut telah dinilai jaksa sudahP21, kemudian siap diajukan untuk di sidangkan.

6. Bentuk register: SPDP (Surat Pemberitahuan Dimulainya Penyidikan)

Fungsi bahasanya menggunakan fungsi informasional, yaitu untuk menginformasikan sesuatu.Makna bahasanya menggunakan makna leksikal, karena maknanya sesuai dengan hasil observasi alat indra atau makna yang sungguh-sungguh nyata. SPDP memiliki arti sebagai surat pemberitahuan bahwa polisi/penyidik telah memulai penyidikan atas suatu tindak pidana, lalu penyidik memberitahukan hal itu kepada Penuntut Umum melalui SPDP tersebut.

Konteks: Pihak kepolisian memberikan SPDP kepada jessica wongso sebagai pemberitahuan dimulainya pemeriksaan.

7. Bentuk register: BAP (Berita Acara Penyidikan)

Fungsi bahasanya menggunakan fungsi informasional, yaitu untuk menginformasikan sesuatu. Sesuatu dimaksudkan di sini adalah berita acara penyidikan. Makna bahasanya menggunakan makna leksikal, karena maknanya sesuai dengan hasil observasi alat indra atau makna yang sungguh-sungguh nyata. BAP memiliki arti sebagai informasi atau alat bukti yang diakui dalam ranah hukum pidana, yakni keterangan saksi, keterangan ahli, surat, petunjuk, dan keterangan terdakwa atau BAP dibuat berdasarkan keterangan saksi atau terdakwa. Bukan berdasarkan apa yang didengar, dilihat, atau yang dialami oleh penyidik secara langsung.

Konteks: Dalam kasus kematian Mirna, teman sekaligus saksi telah mendapatkan berita acara penyelidikan untuk mengungkap siapa dalang dari kematian Mirna ini.

8. Bentuk register: KUHP dan KUHAP

Fungsi bahasanya menggunakan fungsi regulatorik, yaitu fungsi untuk mempengaruhi, mengatur, dan mengendalikan masyarakat dalam bertindak lewat pasal dan undang-undang yang berlaku.Makna bahasanya menggunakan makna konotatif, karena maknanya mempunyai nilai rasa positif maupun negatif. Nilai rasanya berupa undang-undang yang telah ditetapkan, baik yang bernilai positif maunpun negatif tetapi tetap menegakkan keadilan untuk kepentingan masyarakat. KUHP dan KUHAP merupakan singkatan untuk mengungkapkan sesuatu.KUHP adalah Kitab Undang-undang Hukum Pidana, sedangkan KUHAP adalah Kitab Undang-undang Hukum Acara Pidana.

Konteks: Perbuatan penggelapan oleh pegawai negeri (Pasal 41 KUHP) membuat palsu atau memalsukan (Pasal $416 \mathrm{KUHP}$ ), menerima pemberian atau janji $(418,419$, dan $420 \mathrm{KUHP})$, serta menguntungkan diri sendiri atau orang lain secara melawan hukum (Pasal 423, 425, dan 435 KUHP). Ini termasuk pasal-pasal untuk pemberantasan korupsi. Kemudian Pasal 183 KUHAP 
mensyaratkan adanya dua alat bukti yang sah, ditetapkan oleh undang-undang, dan keyakinan hakim bahwa tindak pidana telah terjadi dan terdakwalah yang bersalah melakukannya.

9. Bentuk register: eksploit

Fungsi bahasanya menggunakan fungsi direktif, yaitu fungsi yang digunakan untuk mempengaruhi lawan bicara. Makna bahasanya menggunakan makna konseptual, karena maknanya sesuai dengan konsep. Eksploit memiliki arti sebagai surat pemberitahuan dari juru sita kepada yang tersangkut perkara pengadilan dalam suatu akte yang meminta agar yang bersangkutan segera menghadap pengadilan pada hari dan jam yang telah ditentukan. Konsepnya berupa surat pemberitahuan yang isinya terdapat hari dan jam untuk menghadap ke pengadilan.

Konteks: Setelah konsinyasi, pengadilan memberikan eksploit/memanggil tergugat untuk menyerahkan uang dari penggugat sebagai pembayaran hutang.

10. Bentuk register: aspek yuridis

Fungsi bahasanya menggunakan fungsi regulatorik, yaitu fungsi bahasa yang digunakan untuk mengatur dan mengendalikan orang lain. Bahasa hukumnya yang memuat pasal-pasal beserta kandungannya dapat mengendalikan masyarakat.Makna bahasanya menggunakan makna konotatif karena maknanya mempunyai nilai rasa, baik positif maupun negatif. Nilai rasanya dinilai secara hukum. Aspek yuridis memiliki arti menurut hukum atau secara hukum.

Konteks: Melalui analisis dan berbagai penafsiran maka dapat disebutkan bahwa pembentuk undang-undang merasakan Bab XVIII KUHP serta Peraturan Penguasa Perang Pusat Prt/Perperpu/013/ 1958 dan Peraturan Penguasa Perang Pusat Kepala Staf Angkatan Laut Prt/Z.I/I/7 tanggal 17 April 1958 (diumumkan dalam Berita Negara Nomor: 42 Tahun 1958) ditinjau dari aspek yuridis dalam perkembangan masyarakat kurang dapat berperan dalam menanggulangi perbuatan korupsi.

\section{PEMBAHASAN}

\section{Bentuk Register Bahasa Hukum}

Bentuk register bahasa hukum memiliki banyak bentuknya. Bentuk awalnya bersumber pada istilah yang terdapat dalam bahasa hukum, khususnya profesi advokat berasal dari bahasa Belanda, bahasa Inggris, dan bahasa Indonesia.

Bahasa hukum berawal dari bahasa Belanda, kemudian diterjemahkan kedalam bahasa Indonesia tetapi banyak juga yang masih menggunakan bahasa Belanda, seperti eigendom, schuld in enge zin, vermijdbaar, vermijtbaar, dan lain-lain.

Bahasa hukum juga terdapat proses penyerapan dalam bahasa Inggris. Karena bahasa hukum merupakan bahasa yang digunakan dalam berkomunikasi orangorang kalangan menengah keatas, seperti latent, manifest, contempt of court, dan lain-lain. Bahasa hukum di Indonesia merupakan proses penyerapan dari bahasa Belanda dan bahasa Inggris yang diserap kedalam bahasa Indonesia. Kemudian bermunculan istilah khas yang digunakan dalam bahasa hukum di Indonesia, seperti pledoi, replik, duplik, vonis, dan lain-lain.

2. Fungsi Register Bahasa Hukum

Fungsi register bahasa hukum merupakan fungsi untuk menyampaikan konsep, gagasan, dan pikiran yang mengutamakan peraturan dalam mewujudkan 
keadilan dan ketertiban dikalangan masyarakat. Fungsi register bahasa hukum juga untuk memperlancar komunikasi di dalam maupun luar persidangan antar pihak-pihak yang berkecimpung di dunia hukum, seperti advokat, polisi, jaksa, hakim.

Berdasarkan analisis data register bahasa hukum memiliki beberapa fungsi. Fungsi tersebut yaitu fungsi referensial, fungsi regulatorik, fungsi informasional, fungsi kontektual, fungsi interaksional, fungsi personal, fungsi konatif, fungsi ekspresif, fungsi representasi, fungsi direktif, fungsi fatik, dan fungsi transaksional.

3. Makna Register Bahasa Hukum

Makna register bahasa hukum merupakan makna/arti yang terkandung dalam istilah khusus di dunia hukum. Banyak makna yang terkandungdidalamnya bila berbicara mengenai hukum, tetapi satu register hanya memiliki satu makna sehingga pihak-pihak yang berkecimpung di dunia hukum dapat mengetahui apa yang sedang dipermasalahkannya.

Berdasarkan analisis data register bahasa hukum memiliki beberapa makna bahasa. Makna bahasa tersebut yaitu makna referensial, makna denotatif, makna konotatif, makna konseptual, makna leksikal, dan makna istilah.

\section{SIMPULAN}

Bahasa hukum dianggap sebagai bahasa yang mencari kebenaran dan keadilaan bagi masyarakat. Terutama para advokat, mereka mencari keadilan bagi kliennya yang membutuhkan keadilan bagi yang bersalah maupun tidak bersalah. Bentuk atau wujudnya banyak menggunakan kata dalam istilah bahasa Indonesia di bidang hukum, seperti praduga tak bersalah, konsinyasi, dan sebagainya.

Sedangkan, Fungsi bahasa di bidang hukum sering menggunakan fungsi regulatorik karena fungsi ini digunakan untuk mengatur dan mengendalikan masyarakat lewat undang-undang yang berlaku. Selanjutnya fungsi referensial karena fungsinya dilihat dari referensi/acuan untuk membicarakan suatu peristiwa. Ada fungsi bahasa lainnya yaitu menggunakan fungsi informasional, fungsi kontektual, fungsi interaksional, fungsi personal, fungsi konatif, fungsi ekspresif, fungsi representasi, fungsi direktif, fungsi fatik, dan fungsi transaksional. Terakhir, makna bahasanya sering digunakan di bidang hukum yaitu makna referensial, makna denotatif, dan makna konseptual. Ada makna bahasa yang lainnya yaitu makna leksikal dan makna istilah.

\section{SARAN}

Masyarakat umum sedikitnya harus mengenal dan mengetahui beberapa istilah khusus yang dimiliki oleh hukum di Indonesia. Sehingga bila masyarakat umum terkena masalah hukum, mereka dapat paham dan tidak salah dalam mengambil suatu langkah dalam menjalani suatu proses hukum. Tetapi lebih baiknya bila masyarakat tidak melanggar aturan perundang-undangan yang berlaku. 


\section{DAFTAR PUSTAKA}

Halliday, Ruqaiya Hasan. 1994. Bahasa, Konteks, dan Teks: Aspek dan Bahasa dalam Pandangan Semiotika Sosial (terjemahan Asrudin Barori Tou). Yogyakarta: Gajah Mada University Press.

Mahsun. 2012. Metode Penelitian Bahasa. Jakarta: PT Raja Grafindo Persada. 